\title{
Male gonadal function in coeliac disease: 2. Sex hormones
}

\author{
M J G FARTHING, ${ }^{*}$ L H REES, C R W EDWARDS, AND A M DAWSON \\ From the Department of Gastroenterology and of Endocrinology, St Bartholomew's Hospital, London
}

SUMmary Hypogonadism, infertility, and sexual dysfunction occur in some men with coeliac disease. We have measured plasma testosterone, dihydrotestosterone, sex-hormone binding globulin, oestradiol, and serum luteinising hormone in 41 men with coeliac disease and have related these findings to jejunal morphology, fertility, semen quality, and sexual function. To determine the specificity of these observations in coeliacs we also studied 19 nutritionallymatched men with Crohn's disease, and men with chronic ill-health due to rheumatoid arthritis and Hodgkin's disease. The most striking endocrine findings in untreated coeliacs were increased plasma testosterone and free testosterone index, reduced dihydrotestosterone (testosterone's potent peripheral metabolite), and raised serum luteinising hormone, a pattern of abnormalities indicative of androgen resistance. As jejunal morphology improved hormone levels appeared to return to normal. This specific combination of abnormalities was not present in any of the disease control groups and, to our knowledge, androgen resistance has not been described previously in any other non-endocrine disorder. Plasma oestradiol concentration was modestly raised in $10 \%$ of coeliacs and $11 \%$ of patients with Crohn's disease. Unlike plasma androgens and serum luteinising hormone in coeliacs, plasma oestradiol was not clearly related to jejunal morphology. Androgen resistance and associated hypothalamic-pituitary dysfunction appear to be relatively specific to coeliac disease and cannot be explained merely in terms of malnutrition or chronic ill-health. In addition, our findings suggest that this endocrine disturbance may be related to sexual dysfunction in coeliac disease but its relationship to disordered spermatogenesis in this condition has not been clearly established.

Hypogonadism is known to occur in some men with coeliac disease $1+$ and was found in $7 \%$ of patients in our recent survey. Sexual dysfunction unaccompanied by other clinical features of hypogonadism was found more commonly.' Infertility in coeliacs has been reported in limited case studies" and improvement in semen quality and suceessful pregnancy in previously infertile women was associated with gluten withdrawal. We found that 19'; of male coeliacs had infertile marriages." a value considerably higher than that expected in the general population."

The pathophysiological mechanisms responsible for infertility. sexual dysfunction. and overt hypogonadism are not clearly understood. We have been unable to attribute these ahnormalities to

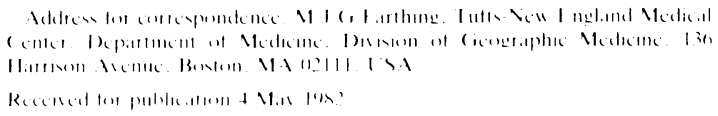

general nutritional status or specific deficiencies of vitamin $B_{12}$ or folic acid. Reversible androgen resistance" and hyperprolactinaemia." however. have heen described in men with coeliac disease. which in other conditions are reported to cause infertility ${ }^{\prime \prime}$ and sexual dysfunction. ${ }^{12}$ 1.3 These ahnormalities. however. have not been clearly shown to be specific features of coeliac disease nor have they been related to infertility and sexual dystunction in this condition.

The primary aim of the present study wals to investigate some endocrine aspects of gonadal function in men with coeliac disease and to relate these findings to jejunal morphology. fertility. semen quality. and sexual function. To determine the specificity of these findings in coeliac disease we also investigated nutritionally-matched men with (rohn s discase. and men with chronic ill-health due to rheumatoid arthritis and untreated Hodgkins discase. 


\section{Methods}

\section{PATIENTS}

Forty-one consecutive males with coeliac disease (median age 36 years, range 15-71 years) were studied and observations in these patients were compared with those of 19 men with Crohn's disease (median age 29 years, range 15-58 years), 18 men with untreated Hodgkin's disease (median age 31 years, range $17-57$ years), 13 men with seropositive rheumatoid arthritis (median age 57 years, range 40-68 years), none of whom was receiving corticosteroid therapy, and 27 healthy male control subjects (median age 29 years, range 22-58 years). Patients with Hodgkin's disease and rheumatoid arthritis were taken as examples of malignant and non-malignant chronic ill-health. All patients gave their informed consent before taking part in the study.

DIAGNOSIS AND DISEASE ACTIVITY

The diagnosis of coeliac disease was based on the morphological appearances of an initial jejunal biopsy with subsequent improvement in jejunal morphology after gluten withdrawal. Patients were classified according to jejunal histology into three groups - namely, subtotal villous atrophy, partial villous atrophy, or a normal mucosa as described previously."

The patients with Crohn's disease all had both colonic and small intestinal disease with characteristic radiological and histological features. Disease activity was assessed using an activity score $^{1+}$ (CDAS) which took into account clinical data and the results of laboratory investigations.

At the time of study, three patients were receiving prednisolone $3-5 \mathrm{mg}$ daily, three were receiving sulphasalazine 1-3 g daily, and five azathioprine. 2 $\mathrm{mg} / \mathrm{kg} / \mathrm{day}$. A total of eight patients were receiving one or more of these drugs but the remaining 11 were receiving none.

NUTRITIONAI. STATUS, CIINICAI. FEATURES OF HYPOGONADISM. AND FERTILITY

Standard anthropometric data and serum albumin concentration reported previously $y^{5}$ indicated that general nutritional status was not significantly different in these patients with coeliac disease and those with Crohn's disease. Clinical features. fertility, and semen quality in these patients have been reported in detail but will be related to the endocrine findings in the present study when appropriate.

PROCEDLRF

Blood samples for hasal hormones were taken between $09.00 \mathrm{~h}$ and $10.00 \mathrm{~h}$ in non-fasting subjects 60 minutes after introduction of a heparin-free silicone elastomer cannula into a forearm vein. ${ }^{15}$ Serum or plasma was stored at $-20^{\circ} \mathrm{C}$ before analysis.

Plasma testosterone and dihydrotestosterone were measured by radioimmunoassay using an antibody raised by immunisation with a 3-oxime derivative of testosterone conjugated with bovine serum albumin. Cross-reactivity studies showed $98 \%$ cross-reactivity between testosterone and dihydrotestosterone but less than $5 \%$ with all other steroids tested. Plasma samples were extracted with diethyl ether, and testosterone and dihydrotestosterone were separated by celite microcolumn chromatography. ${ }^{9} 1617$ Plasma sex-hormone binding globulin (SHBG) was measured by a modification of the method of Rosner, ${ }^{18}$ from which the free testosterone index was derived using the expression, percentage unbound testosterone $=2 \cdot 3-11.4\left(\log _{10}\right.$ plasma-SHBG) as described previously. ${ }^{9}$

Plasma oestradiol-17 $\beta$ was determined by a previously described radioimmunoassay using an antibody raised against an oestradiol-6-oxime bovine serum albumin conjugate. ${ }^{19}$ Luteinising hormone was measured by double-antibody radioimmunoassay and results expressed as $U / 1$ of $M R C$ standard $68 / 40$. Inter- and intra-assay variation were less than $10 \%$ for all radioimmunoassays. Complete hormone data were not available in every patient. but this is evident from the figures in the results section.

\section{STATISTICAL. ANALYSES}

Comparisons between groups of patients and control subjects were examined by the MannWhitney U test.

\section{Results}

PLASMA ANDROGENS AND SEX HORMONE BINDING GI.OBULIN

Total plasma testosterone concentration (Fig. 1) was higher in men with untreated coeliac disease than patients with Crohn's disease. Hodgkin's disease. rheumatoid arthritis $(\mathrm{p}<() \cdot()() 1)$, and healthy control subjects $(p<() \cdot() 1)$. In addition; plasma testosterone was lower in treated coeliacs with a normal jejunal mucosa than those with untreated or partially treated coeliac disease $(p<0 \cdot(1) 25)$.

Plasma SHBC (Fig. 2) was greater in coeliacs with subtotal villous atrophy and partial villous atrophy than those with a normal jejunal mucosa $(p<0(0) 1)$. Patients with (rohn's disease. Hodgkin's disease. and rheumatoid arthritis, however, also had 


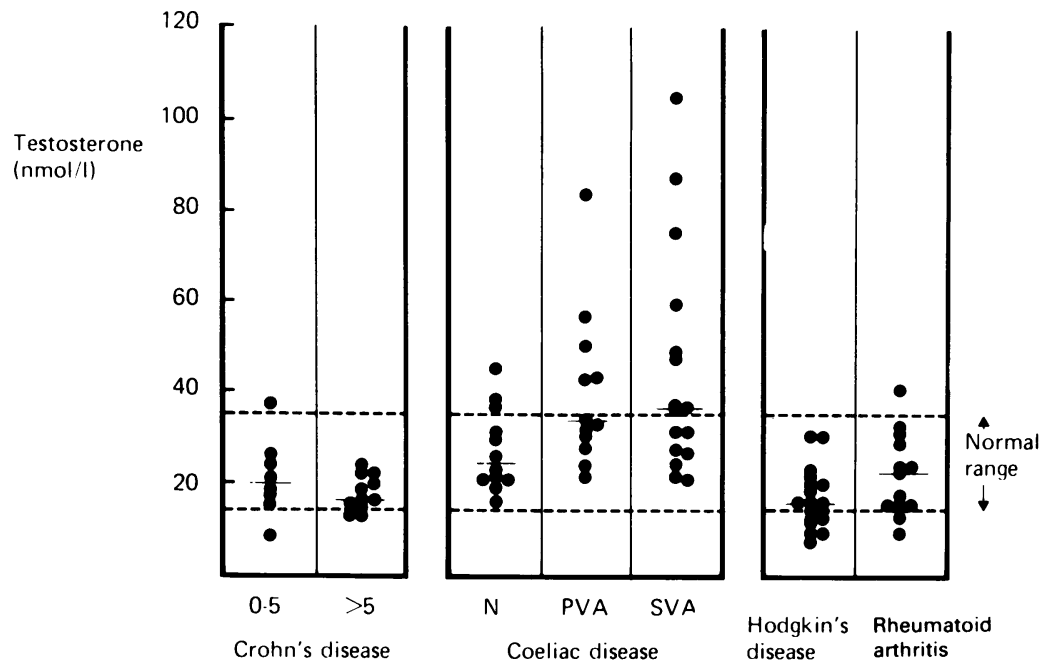

Fig. I Plasma lestosterone concentration in men with coeliac dise'ase' ( N, normal jejunal mucosa; PVA, partial rillous atrophy: SVA. subtotal villous atrophy\%. Crohn's disease' (CD) subdivided into low and high disease activity score groups, ()-5 and $>5$ units. respectively. Hodgkin s dise'ase $(H D)$ and rhe'umatoid arthritis $(R A)$. Horizontal bars represent median

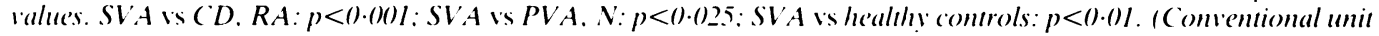
'quivalents in this and following Figures: testosterone', $1 \mathrm{ng} \mathrm{ml}=3.47 \mathrm{nmol} /$ : sex hormone binding globulin. $I$

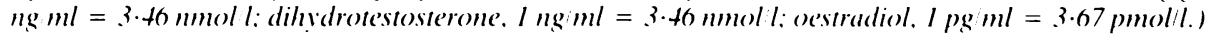

significant rises in plasma SHBG compared with healthy control subjects $(\mathrm{p}<0 \cdot() 1)$ which were not significantly different from men with untreated coeliac disease. This increase in plasma SHBG in men with coeliac disease did not account for the rise in total plasma testosterone, as the free testosterone index (Fig. 3) remained significantly higher in coeliacs with subtotal villous atrophy and partial villous atrophy than in patients with Crohn's disease. Hodgkin 's disease, and rheumatoid arthritis $(\mathrm{p}<() \cdot()() 1)$.

Plasma dihydrotestosterone concentration (Fig. 4) was lower in coeliacs with subtotal villous atrophy than in those with partial villous atrophy or normal mucosa $(p<0 \cdot(05)$. Plasma dihydrotestosterone was lower in patients with high activity Crohn's disease
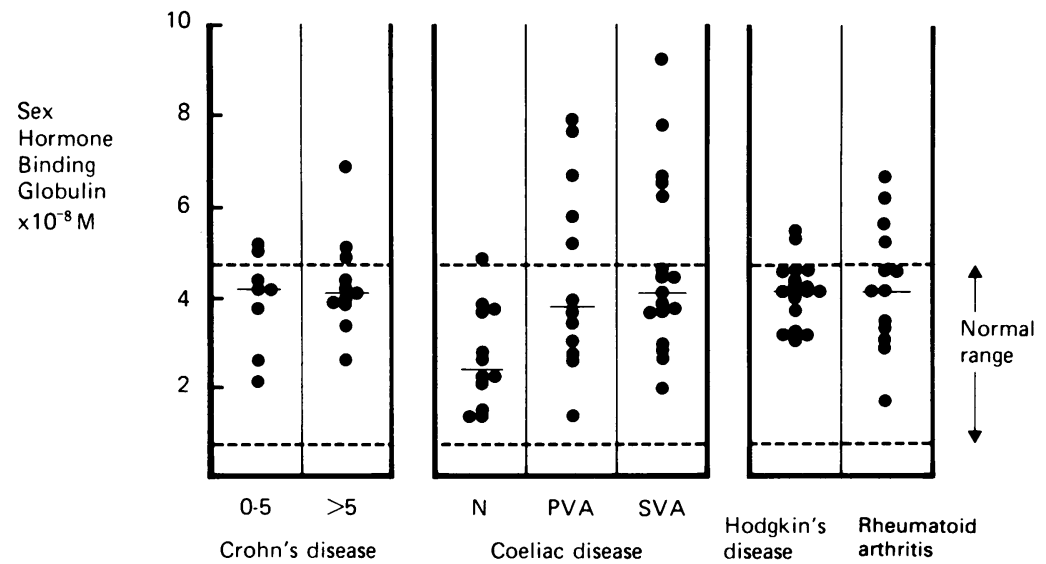

Fig. 2 Plasma sex hormone binding globulin concentration in men with coeliac disease and controls. SVA. PVA vs $N$ : $p<(0 \cdot 01:$ CD. HD. RA is healthy controls: $p<0 \cdot 01$. 


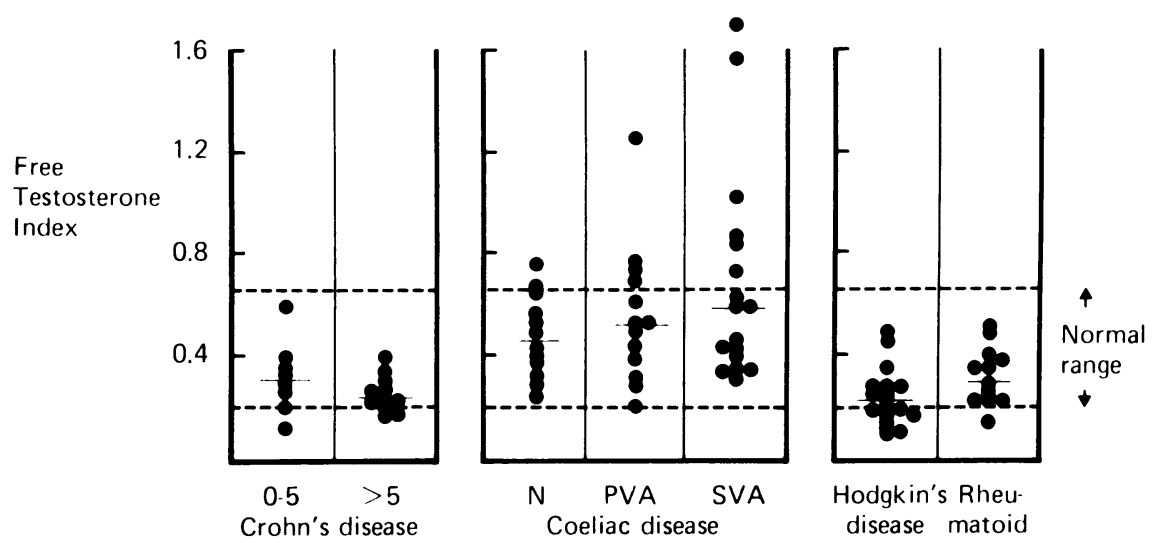

Fig. 3 Free testosterone index in men with coeliac disease and controls. SVA. PVA ws ( I). HI), RA: $<<() \cdot()) I$.

(CDAS $>5$ units) and Hodgkin's disease than in healthy controls $(\mathrm{p}<0) \cdot(05)$.

These abnormalities of plasma androgens and SHBG appeared progressively to return to normal as jejunal morphology recovered after gluten was withdrawn from the diet.

\section{Plasma oestradiol}

Although plasma oestradiol concentration in patients with coeliac disease as a group (median 337 $\mathrm{pmol} / \mathrm{l}$, range 216-557) did not differ significantly from patients with Crohn's disease (median 288 $\mathrm{pmol} / \mathrm{l}$. range 197-712) or healthy control subjects (median $285 \mathrm{pmol} / \mathrm{l}$, range 140-37()), two of 21 coeliacs (one with subtotal villous atrophy and one with partial villous atrophy and two of 18 patients with (rohn's disease had raised plasma oestradiol. Overall, there was no obvious relationship between plasma oestradiol concentration and disease activity in either coeliac disease or Crohn's disease.

SERUM L.UTEINISING HORMONE

Serum luteinising hormone concentration in coeliacs with subtotal villous atrophy was higher than in normal controls $(p<0 \cdot() 1)$ and patients with high activity Crohn's disease $(p<0) \cdot() 1$; Fig. 5). In addition. coeliacs with subtotal villous atrophy had higher serum luteinising hormone concentration than those with a normal jejunal mucosa $(p<0) \cdot(0) 1)$, suggesting that the abnormality returns towards normal after gluten withdrawal and improvement in jejunal morphology.

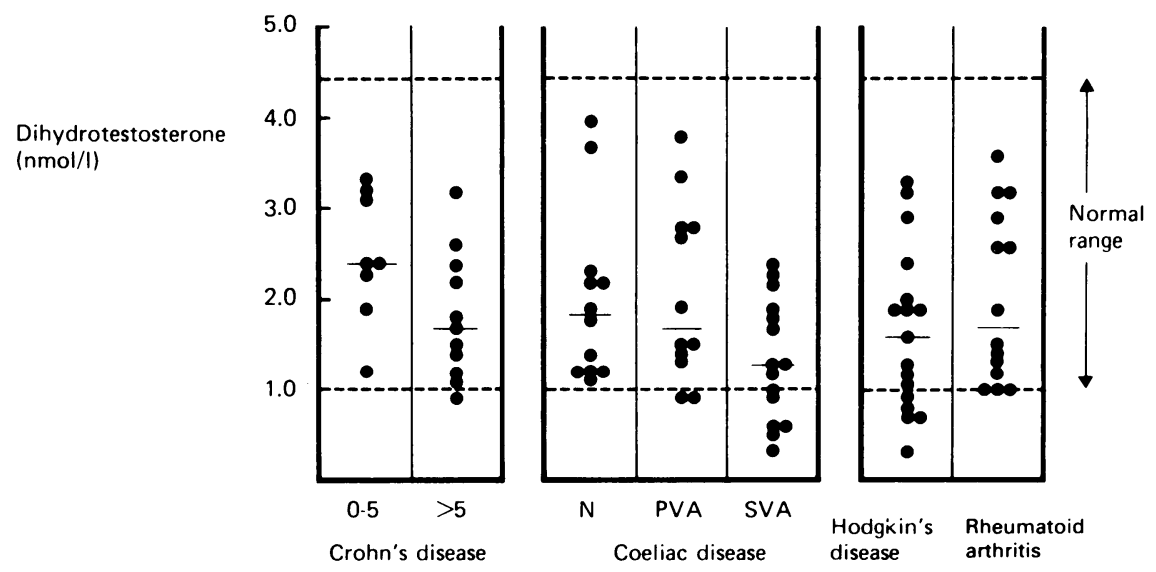

Fig. 4 Plasma dihydrotestosterone concentration in men with coeliac disease and controls. SVA vs PVA, N: $P<() \cdot(05: H D$. high activity ( $D$ vs healthy controls: $p<0 \cdot(05$. 

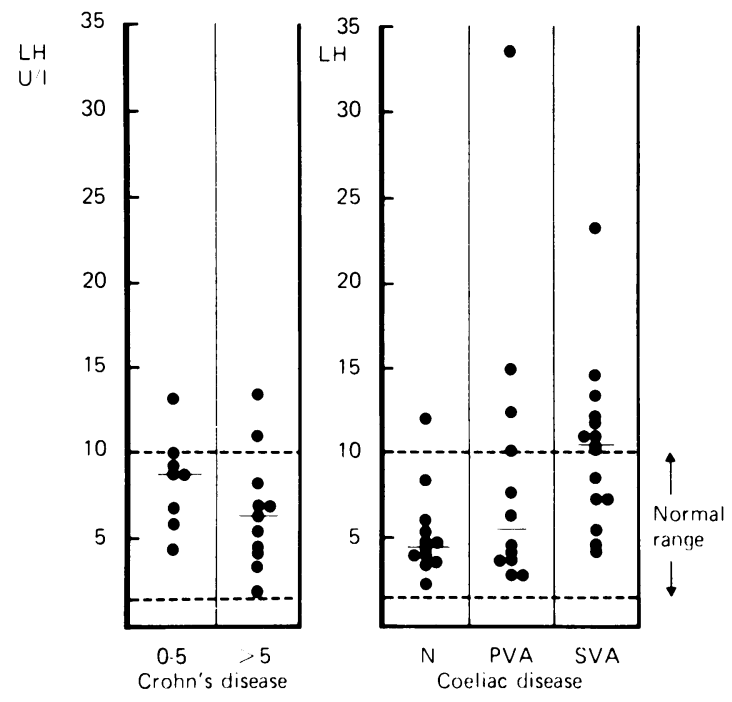

Fig. 5 Serum luteinising hormone (L.H) in men with coeliac disease and (rohn's dise'ase. SVA is high activity (I), healthy controls: $p<0 .(1) l:$ SVA is $N: p<0) \cdot(0)$ I.

FNDOCRINESIATCSOF PATIENTS WITH SEXLAI D)YSLN(IION ANI) INFFRIIIE MARRIAGES

Table I summarises the endocrine findings of five of 28 coeliacs $\left(1 \delta^{\prime} ;\right)$ who were found to have persistent (patients 1 and 2) or intermittent erectile impotence. Patients 1 and 2 had clinical evidence of hypogonadism with reduction in facial and body hair, and patient 1 had small soft testes with a mean testicular volume $12 \mathrm{ml}$. normal $>15 \mathrm{ml}$. $^{20}$ There were no endocrine abnormalities that clearly distinguished these patients with impotence from coeliacs with normal sexual function. Plasma testosterone concentration and free testosterone index in impotent coeliacs tended. however. to be lower than other coeliacs of the same morphological subgroup (always below the median value). although plasma testesterone was within the normal range.
Three coeliacs (19\% of married coeliacs) failed to produce children despite regular coitus. There were no obvious endocrine features (Table 2) that differentiated these patients from coeliacs of proven fertility. Seminal analysis in patients 1 and 3 showed markedly reduced sperm motility. $10 \%$ and $25 \%$ respectively (normal $>60 \%)^{21^{\circ}}$ although sperm density and the proportion of abnormal forms of spermatozoa were within the normal range ${ }^{21}$ at $>40$ million $/ \mathrm{ml}$ and $<30 \%$, respectively. Patient 2 was unable to produce an ejaculate because of impotence.

\section{Discussion}

The present study demonstrates a variety of abnormalities of hypothalamic-pituitary-gonadal function in men with coeliac disease which may be of aetiological importance in the production of sexual dysfunction and infertility in some of these patients. Chronic ill-health and malnutrition may. however, influence gonadal function and its regulation: :2 it independently of any specific effects of the primary disease. Our observation that these patients with coeliac disease and those in the gastrointestinal control group with Crohn's disease had similar objective measures of general nutritional status ${ }^{5}$ means that the endocrine abnormalities in coeliacs are likely to be related to the disease rather than the general effects of poor nutrition.

The striking rise in the concentration of plasma testosterone in untreated male coeliacs. which appeared to return to normal after gluten withdrawal and recovery of the jejunal mucosa. confirms the findings of a previous report." Although its major binding protein. $\mathrm{SHBG}^{-5}$ was also raised. this was insufficient to account for the rise in total plasma testosterone, as the free testosterone index was also markedly raised. The association of this abnormality with the significant reduction in plasma dihydrotestosterone concentration and the inappropriately high luteinising hormone concentration is reminiscent of the pattern of endocrine disturbance of androgen resistance.

Iable I Enderrine status of impolent coeliacs

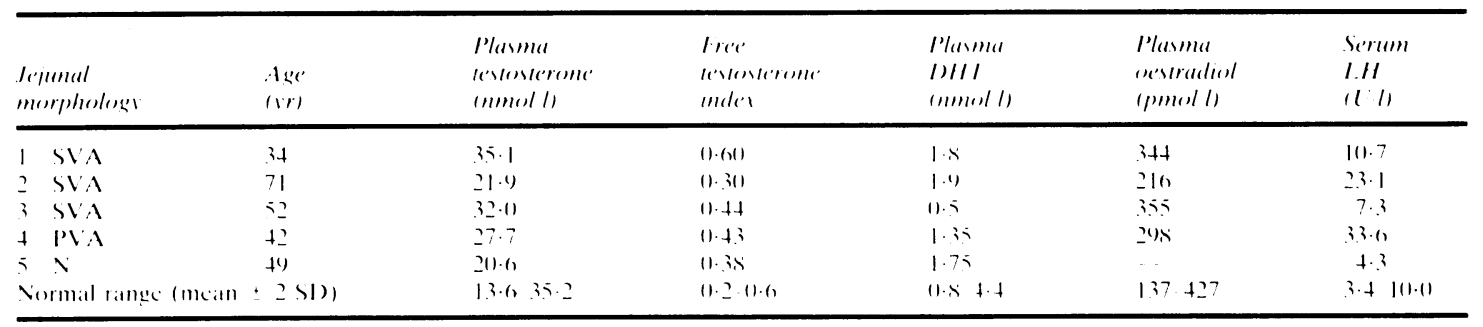


Table 2 Endocrine status of coeliacs with infertile marriages

\begin{tabular}{|c|c|c|c|c|c|c|}
\hline $\begin{array}{l}\text { Jejunal } \\
\text { morphology }\end{array}$ & $\begin{array}{l}\text { Age } \\
(y r)\end{array}$ & $\begin{array}{l}\text { Plasma } \\
\text { testosterone } \\
\text { (nmolil) }\end{array}$ & $\begin{array}{l}\text { Free } \\
\text { testosterone } \\
\text { index }\end{array}$ & $\begin{array}{l}\text { Plasma } \\
D H T \\
\text { (mmoll) }\end{array}$ & $\begin{array}{l}\text { Plasma } \\
\text { oestradiol } \\
\text { (pmol/l) }\end{array}$ & $\begin{array}{l}\text { Serum } \\
L H \\
(U / l)\end{array}$ \\
\hline I SVA & 49 & $48 \cdot 8$ & 0.46 & $2 \cdot 2$ & 312 & $5 \cdot 4$ \\
\hline 2 SVA & 71 & $21 \cdot 9$ & $(0.30$ & 1.9 & 216 & $23 \cdot 1$ \\
\hline $3 \mathrm{~N}$ & 36 & $35 \cdot 3$ & 0.66 & $1 \cdot 8$ & 414 & $8 \cdot 3$ \\
\hline \multicolumn{2}{|c|}{ Normal range (mean $\pm 2 \mathrm{SD}$ ) } & $13 \cdot 6-35 \cdot 2$ & $(0 \cdot 2-0 \cdot 6$ & $0.8-4 \cdot 4$ & $1.37-427$ & $3 \cdot 4-10 \cdot()$ \\
\hline
\end{tabular}

exemplified by the incomplete testicular feminisation syndrome, ${ }^{26}$ particularly that variant due to deficiency of the enzyme $5 \alpha$-reductase. ${ }^{27} 28$ Similar findings have also been described in men receiving the antiandrogen, cyproterone.$^{29}{ }^{311}$ To our knowledge. androgen resistance has not been described in any other non-endocrine disease.

The reduction of testosterone to dihydrotestosterone by the enzyme $5 \alpha$-reductase is essential for the full expression of androgenicity in androgen target-organs such as prostate and seminal vesicles ${ }^{31}$ and it is this peripheral conversion of testosterone that contributes the major part of the circulating plasma dihydrotestosterone. ${ }^{32} .3 .3$ These findings suggest that, in men with untreated coeliac disease. there is a failure of peripheral $5 \alpha$-reduction of testosterone to dihydrotestosterone. It has been suggested that, as this abnormality is reversible in coeliac disease and that correction of plasma androgen levels coincides with improvement in jejunal morphologv. the gut mucosa may be an important site for the conversion of testosterone to dihydrotestosterone." Although $5 \alpha$-reductase is present in mammalian intestinal mucosa $a^{3+35}$ we have shown recently that it is unlikely to be an important contributor to the peripheral reduction of testosterone in vivo. ${ }^{36}$

Failure of the high circulating levels of testosterone to suppress luteinising hormone suggests that the hypothalamic-pituitary system is insensitive to the normal inhibitory feedback action of plasma testosterone. $5 \alpha$-reductase is present in the pituitary and hypothalamus and conversion of testosterone to dihydrotestosterone in the central nervous system may be an important link in the feedback control of luteinising hormone secretion. ${ }^{31}$ Hence, central as well as peripheral conversion of testosterone to dihydrotestosterone may be impaired in untreated male coeliacs.

This pattern of plasma androgen abnormality in males with coeliac disease was not found in nutritionally-matched men with Crohn's disease nor in the chronic disease control groups with Hodgkin's disease or rheumatoid arthritis. In these conditions plasma testosterone and dihydrotestosterone both tended to be low or low normal, which is similar to the findings in other chronic illnesses ${ }^{37} .38$ and malnutrition in $\operatorname{man}^{39}$ and animals. ${ }^{+1}+1$ This difference emphasises the specificity of the disturbance of plasma androgens in coeliac disease.

The reason for the rise in plasma SHBG in untreated coeliac disease is not clear, although it occurred in the other non-gastrointestinal control groups. and may therefore be a feature of chronic illness. Although oestrogens increase plasma SHBG concentration $^{+5}$ it would seem unlikely that the unimpressive increments of plasma oestradiol found in a few patients can account for this abnormality in coeliac disease.

\section{ENDOCRINE ABNORMALITIES AND SEXUAL}

DYSFUNCTION

We have shown previously in these patients with coeliac disease that impotence occurred more commonly than expected in the general population. ${ }^{5}$ In addition. sexual activity in coeliacs was reduced compared with men with Crohn's disease matched for age and nutrition. Although it is assumed that testosterone is required for normal sexual response. until recently there have been few studies to confirm this clinical impression. Ismail et $a l^{+3}$ found lower testosterone concentrations in men with gradual onset impotence and low libido, than in impotent men with normal sexual interest. The low normal plasma testosterone observed in the impotent coeliacs with diminished libido, in association with underlying androgen resistance. may be an important contributory factor to the sexual dysfunction of these patients. Our findings that androgen-dependent facial hair growth is disturbed in coeliac disease supports the view that these abnormalities of plasma androgens are phỵsiologically significant. ${ }^{+4}$

ANI)ROGEN RESISTANCE ANI) INFERTIIITY

In a previous study we were unable to identify any general or specific nutritional deficiencies that could account for infertility or the abnormalities in semen quality in coeliac disease." Androgen resistance. however, associated with reduction of the high 
affinity cytosolic dihydrotestosterone binding protein. can cause severe oligospermia or azoospermia." It has been suggested that dihydrotestosterone might stimulate the advanced stages of spermatogenesis ts and significant reduction of dihydrotestosterone concentration has been found in the seminal plasma of azoospermic men. ${ }^{+1}{ }^{+}$ Local androgen resistance within the testis and accessory sex organs may be an additional factor in the alteration of semen quality in coeliac disease. although the limited improvement in semen qualits after gluten withdrawal." despite reversal of the androgen resistance. suggests that this is not a straightforward association.

Although we were unable to implicite abnormalities of serum vitamin $B_{1}$, or red cell folate in impairment of semen quality in coeliacs." deficiency of other vitamins or trace metals may bo important.

GILTEN PEPTIDES AND HYPOTHAIAMIC-

PITLITARY DYSFLNCTION

The findings of the present study suggest that hypothalamic-pituitary regulation of gonadal function is impaired in coeliac disease. ${ }^{+\infty}+4$ Growth hormone secretion and the regulation of thyroid function $^{51} 51$ are also disturbed in coeliac disease. Our findings in the present and previous studies ${ }^{5} \mathrm{si}$ indicate that these changes occur independently of the mild to moderate reduction in general nutritional status. suggesting that other factors are important.

Gluten peptides, particularly their major consitutuent $\alpha$-gliadin, are thought to be the toxic components of some cereal grain proteins that cause the enteropathy of coeliac disease in susceptible individuals. $:-$ In addition. gluten peptides may be involved in the pathogenesis of some behavioural and psychiatric disorders." Recently, gluten peptides have been shown to enter the rat brain ${ }^{5+}$ and to have opioid activity.

Naturally occurring peptides with opioid properties have endocrine effects in man. ${ }^{56}$ the principal site of action being the hypothalamus. It is possible that circulating gluten peptides may contribute to the hypothalamic-pituitary dysfunction of coeliac disease.

MJGF gratefully acknowledges the financial support of the Wellcome Trust. The authors are indebted to the staff of the Williamson Laboratory. St Bartholomew's Hospital, for performing the seminal analyses. to Professor J Malpas and the Department of Oncology. St Bartholomew's Hospital. for providing serum of men with Hodgkin's disease. and to Cindy Heim for typing the manuscript. The authors also wish to express their gratitude to Dr Parreen Kumar. Department of (iastroenterology. St Bartholomews Hospital. and to Dr Robert Bown. Frimley Park Hospital. for allowing us to investigate their patients with coeliac disease.

\section{References}

I Bennett TI. Hunter D. Vaughan JM. Idiopathic steatorrhoea (Gee's disease) a nutritional disturbance associated with tetany. osteomalacia and anaemia. QJ Med 1932: 1: 603-78.

z cooke WT. Peeney Al.P. Hawkins CF. Symptoms. signs and diagnostic features of idiopathic stcatorrhoca. (i) J Med 1953: 22: 59-77.

3 Perloff WH. Lasche EM. Nodine JH. Schnecherg NG. Vicillard ( $B$. The starvation state and functional hypopituitarism. JAMA 1954: 155: 13(17-1.3.

+ Barry RE. Batker P. Read AE. Coeliac disease: the clinical presentation. (lin (jastroenterol 1974: 3: 55-69.

5 Farthing MJG. Edwards CRW. Rees LH. Dawson AM. Male gonadal function in coeliac disease: I. Sexual dysfunction. infertility and semen quality. Gut 1982: 23: 608-14.

6 Morris JS. Adjukiewicz AB. Read AE. Cocliac infertility: an indication for dietary gluten restriction? Lancet 1970: 1: 213-4.

7 Baker PG. Read AE. Reversible infertility in male coeliac patients. Br Med J 1975: 2: 316-7.

8 Southam AL. What to do with the normal infertile couple. Fertil Steril 1960); 11: 543-9.

9 Green JRB. Goble HL. Edwards CRW, Dawson AM. Reversible insensitivity to androgens in men with untreated gluten enteropathy. Lancet 1977: 1: 280-2.

10 Stevens FM. McCarthy CF. Craig A. Is prolactin trophic to the intestine in coeliac disease? (Fut 1978: 19: A992-3.

11 Aiman J. Griffin JE. Galzak JM. Wilson JD. MacDonald PC. Androgen insensitivity as a cause of infertility in otherwise normal men. $N$ Engl J Med 1979: 300: 223-7.

12 Friesen H Tolis G. Shui R. Hwang P. In: Pasteels JL. Robyn C. eds. Human prolactin. Amsterdam: Excerpta Medica. 1973.

13 Franks S. Jacobs HS, Martin N. Nabarro JDN. Hyperprolactinaemia and impotence. Clin Endocr 1978: 8: 277-87.

14 Willoughby JMT. Kumar PJ. Beckett J. Dawson AM. Controlled trial of azathioprine in Crohn's disease. Lancet 1971: 2: 944-7.

15 Farthing MJG. Mattei AM. A new cannula for intermittent and continuous venous sampling. $\mathrm{Br} \mathrm{Med} J$ 1979: 2: 112 .

16 Abraham GE. Tulchinsky D. Korenman SG. Chromatographic purification of oestradiol $17 \beta$ for use in radio-ligand assay. Biochem Med 1970: 3: 365-8.

17 Anderson DC. Hopper BR. Lasley BL. Yen SSC. A simple method for the assay of eight steroids in small volumes of plasma. Steroids 1976: 28: 197-6. 
If Rosner W. A simplified method for the quantitative determination of testosterone-estradiol-binding globulin activity in human plasma. J (lin Endocr Me'ab) 1972: 34: 98.3-8.

19 (iolder MP. Phillips MEA. Fahmy DR. Preces P. Jones V. Henk JM. Griftiths K. Plasma hormones in patients with advanced breast cancer treated with tamoxilen. Eur J Cancer 1976: 12: 719-23.

2() Prader A. Testicular size: assessment and clinical importance. Triangle 1966: 7: 241)-3.

21 Laneveld L.JI). Polakoski KL. Collection and physical examination of the ejaculate. In: Hatez ESE. ed Techniques of human andrology. Amsterdam: Elsevier North Holland. 1977.

22 Jacobs EC(. Effects of starvation on sex hormones in the male. J (lin Endocrinol 1948: 8: 227-32.

23 Hultgren HN. Clinical and laboratory observations in severe starvation. Stanford Med Bull 1951: 9: 175-91.

24 de Kretser DM. The effects of systemic disease on the function of the testis. Clin Endocrinol Metab 1979: 8: $487-98$.

25 Anderson DC. Sex-hormone binding globulin. Clin Endocrinol 1974: 3: 69-96.

26 Walsh PC. Madden JD. Harrod MJ, Goldstein JL. MacDonald PC, Wilson JD. Familial incomplete male pseudohermaphroditism, type 2. Decreased dihydrotestosterone formation in pseudovaginal perineoscrotal hypospadias. $N$ Engl J Med 1974; 291: 944-9.

27 Imperato-McGinley J. Guerrero L. Gautier T. Peterson RE. Steroid $5 \alpha$-reductase deficiency in man: an inherited form of male pseudohermaphroditism. Science 1974: 186: 1213-5.

28 Imperato-McGinley J. Peterson RE. Gautier T. Sturla E. Male pseudohermaphroditism secondary to $5 a$ reductase deficiency - a model for the role of androgens in both the development of the male phenotype and the evolution of a male gender identity. $J$ Steroid Biochem 1979: 11: 637-45.

29 Tamm J, Beischer W. The urinary excretion of testosterone and epitestosterone in females following intravenous infusions before and after treatment with an antiandrogen (cyproterone). Acta Endocrinol Kbh 1968; 59: 454-8.

30) Vosbeck K. Keller PJ. The influence of antiandrogens on the excretion of FSH, LH and 17-ketosteroids in males. Horm Metab Res 1971: 3: 273-6.

31 Massa R. Martini L. Testosterone metabolism: a necessary step for activity? J Steroid Biochem 1974: 5: 941-7.

32 Ito T. Horton R. The source of plasma dihydrotestosterone in man. J Clin Invest 1971; 50: 1621-7.

33 Mahoudeau JA. Bardin CW. Lipsett MB. The metabolic clearance rate and origin of plasma dihydrotestosterone in man and its conversion to $5 \alpha$ androstanediols. J Clin Invest 1971; 50: 1338-44.

34 Harri MP. Nienstedt W. Hartiala K. Testosterone metabolism by canine intestine. Suomen Kemistilehti 1970: B11: 395-401

35 Nienstedt W. Ahotupa M. Hietanen E. Metabolism of testosterone and androstenedione by human adult and fetal gastrointestinal tissues in vitro. J Steroid Biochem 1980: 13: 1421-5.
36 Farthing MJG. Vinson GP. Edwards CRW. Dawson AM. Testosterone metabolism by rat gastrointestinal tract. in vitro and in vivo. Gut 1982: 23: 226-34.

37 ('hen JC. Vidt DC;. Zorn EM. Hallberg MC. Wicland R(j. Pituitary levdig cell function in uracmic males. $J$ (lin Endocrinol Metab 1970: 31: 14-17.

38 Mowat NAC;. Edwards ( RW. Fisher R. MeNcilly AS. (jreen JRB. Dawson AM. Hypothalamic-pituitarygonadal function in men with cirrhosis of the liver. (jul 1976: 17: 345-50.

39 Smith SR. (hhetri MK. Johanson AJ. Radfar N. Migeon (J. The pituitary-gonadal axis in men with protein-caloric malnutrition. J (lin Endocrinol Metah 1975: 41: 601-9

4) Baronos S. Mann T. Rowson LEA. Skinner JD. The effect of nutrition and androgens on the composition of hovine blood plasma and seminal plasma at puberty. $\mathrm{Br}$ J Nutr 1969; 23: 191-201.

+1 Howland $B E$. The influence of feed restriction and subsequent refeeding on gonadotrophin secretion and serum testosterone levels in male rats. J Reprod Fertil 1975: 44: 429-36.

42 Pcarlman WH. Crepy E. Murphy M. Testosteronehinding levels in the serum of women during the normal menstrual cycle. pregnancy and the post-partum period. J Clin Endocrinol Metab 1967: 27: 1012-8.

4.3 Ismail AAA. Davison DW. Loraine JA. In: Irvine WJ. ed. Reproductive endocrinolog!: Edinburgh: Livingstone. 1970): 138 .

t4 Rivarola MA. Podesta EJ. Chemes HE, Calandra RS. Androgen metabolism and concentration in the seminiferous tubules at different stages of development. J Steroid Biochem 1975: 6: 36.5-9.

45 Farthing MJG. Mattei AM. Edwards CRW. Dawson AM. Relationship between plasma testosterone and dihydrotestosterone concentrations and male facial hair growth. Br J Dermatol. (In press.)

46 Purvis K. Landgren BM. Cekan Z. Diczfalusy E. Indices of gonadal function in the human male. II. Seminal plasma levels of steroids in normal and pathological conditions. Clin Endocrinol 1975: 4: 24758.

47 Pazzagli M. Giusti G. Forti G. Fiorelli G. MenchiniFabris F. Scarselli GF, Guazzelli R. Conti C. Borrelli D. Cicchi P. Serio M. Seminal plasma levels of testosterone and $5 \alpha$-dihydrotestosterone in azoospermia patients. Clin Endocrinol 1979; 11: 11-14.

48 Vanderschueren-Lodeweyckx M. Wolter R. Molla A. Eggermont E. Eeckels R. Plasma growth hormone in coeliac disease. Helv Paediatr Acta 1973: 28: 349-57.

49 Day G. Evans K. Wharton B. Abnormalities of insulin and growth hormone secretion in children with coeliac disease. Arch Dis Childh 1973; 48: 41-6.

50) Vanderschueren-Lodeweyckx $M$. Eggermont E. Cornette C. Beckers C. Malvaux P. Eeckels R. Decreased serum thyroid hormone levels and increased TSH response to TRH in infants with coeliac disease. Clin Endocrinol 1977: 6: 361-7.

51 Farthing MJG, Rees LH, Edwards CRW, Byfield PGH, Himsworth RL, Dawson AM. Thyroid hormones and the regulation of thyroid function in men with coeliac disease. Clin Endocrinol 1982; 16: 525-35. 
52 Strober W. Gluten-sensitive enteropathy. Clin Gastroenterol 1976: 5: 429-52.

53 Dohan FC. Coeliac disease and schizophrenia. Lancet 197(): 1: 897.

54 Hemmings WA. The entry into the brain of large molecules derived from dietary protein. Proc $R$ Soc Lond [Bioll 1978: 200B: 175-92.
55 Zioudrou C. Streaty RA, Klee WA. Opioid peptides derived from food proteins. The exorphins. $J$ Biol Chem 1979; 254: 2446-9.

56 Stubbs WA, Jones A, Edwards CRW, Delitalia C. Jeffcoate WJ, Ratter SJ, Besser GM. Hormonal and metabolic responses to an enkephalin analogue in normal man. Lancet 1978; 2: 1225-7. 